\title{
STRATEGIES IN DEALING WITH THE READING SECTION OF ‘TOEFL PREDICTION': A CASE OF ACEH EFL LEARNERS
}

\author{
Fera Busfina Zalha*, Alfiatunnur Alfiatunnur, Cut Annisa Triana Kamil \\ UIN Ar-Raniry Banda Aceh, Indonesia \\ (ferabusfina@ar-raniry.ac.id, alfiatunnur@ar-raniry.ac.id, cutkamil97@gmail.com)
}

Received: $04^{\text {th }}$ Sept 2020; Revised: $13^{\text {th }}$ Dec 2020; Accepted: $25^{\text {th }}$ Dec 2020

\begin{abstract}
Highlighting the TOEFL prediction test, this study attempted to explore EFL learners' strategies in dealing with the reading comprehension section of the TOEFL prediction test, both in reading the texts and tackling the questions. This study employed a qualitative research design as its approach and a semi-structured interview as the instrument to gain the data. Six participants were purposively selected from the English Language Education Department of UIN Ar-Raniry Banda Aceh. They were interviewed concerning their reading strategies in dealing with the questions in the TOEFL Prediction test. The findings revealed five strategies used by the participants in contending with the TOEFL reading section, classified into reading strategy and test-taking strategy. The reading strategies consist of skimming and scanning the passages, using context to understand the meaning of unfamiliar vocabulary, and utilizing background knowledge. Meanwhile, reviewing the questions and prioritizing easier questions are included in the testtaking strategy. This study proposes further research to investigate the effectiveness of particular strategies in improving EFL students' performance in facing the reading section.
\end{abstract}

Key Words: Reading Comprehension Section; Reading Strategies; TOEFL Prediction test

\section{ABSTRAK}

Mengangkat topik tes TOEFL Prediksi, penelitian ini mencoba menyelidiki strategi yang dilakukan oleh mahasiswa-mahasiswi Bahasa Inggris dalam menghadapi bagian Reading Comprehension di tes TOEFL, baik strategi ketika membaca teks maupun ketika menjawab soal-soal yang tersedia. Studi ini menggunakan pendekatan qualitatif dan menggunakan wawancara semi-terstruktur sebagai instrument untuk menghasilkan data. Teknik purposive sampling digunakan dalam memilih enam partisipan untuk studi ini yang keenamnya berasal dari Program Studi Pendidikan Bahasa Inggris UIN Ar-Raniry Banda Aceh. Hasil penelitian ini menunjukkan bahwa ada lima strategi yang digunakan oleh partisipan dalam menyelesaikan TOEFL Reading Section. Kelima strategi tersebut dapat diklasifikasikan kepada reading strategy (strategi membaca) dan testtaking strategy (strategi dalam menghadapi tes). Reading strategies terdiri dari membaca teks dengan menggunakan teknik skimming and scanning, menggunakan konteks untuk dapat memahami makna dari katakata yang sukar, dan menggunakan background knowledge (pengetahuan sebelumnya) ketika membaca teks. Sementara mereview pertanyaan dan mengutamakan menjawab pertanyaan-pertanyaan yang lebih mudah termasuk dalam test-taking strategy yang dilakukan oleh partisipan ketika menghadapi tes. Studi ini mendukung penelitian lebih dalam kedepannya terkait keefektifan dari strategi-strategi ini dalam meningkatkan performa mahasiswa-mahasiswi Bahasa Inggris dalam menyelesaikan bagian reading comprehension.

Kata Kunci: Reading Comprehension Section (Bagian Reading Comprehension); Reading Strategies (Strategi Membaca); TOEFL Prediction test (Tes TOEFL Prediksi)

How to Cite: Zalha F.B., Alfiatunnur., Kamil C.A. (2020). Strategies in Dealing With the Reading Section of 'Toefl Prediction': A Case of Aceh EFL Learners. IJEE (Indonesian Journal of English Education), 7(2), 159-171. doi:10.17622/ijee.v7i2.17622

* Corresponding author

IJEE (Indonesian Journal of English Education), 7 (2), 2020, 159-171

P-ISSN: 2356-1777, E-ISSN: 2443-0390 | DOI: http://doi.org/10.15408/ijee.v7i1.17622

This is an open access article under CC-BY-SA license (https://creativecommons.org/licenses/by-sa/4.0/) 


\section{INTRODUCTION}

As a standardized test evaluating an individual's proficiency in understanding the English language, the TOEFL test has been widely used in many aspects of life. One of the TOEFL test's major roles can be vividly seen in the academic or educational sector. For instance, achieving certain scores of TOEFL has been one of the requirements to register as well as to complete the degree at the university level. According to Clark (2014, cited in Halim \& Ardiningtyas, 2018), more than 9,000 colleges and universities in more than 130 countries employ TOEFL scores to help them decide for the admission process. In line with that, in Indonesia, university students (also university student candidates) have to sit for the TOEFL test to measure their English competence so that they can prove that they have met the English standard for university admission or graduation (Netta \& Trisnawati, 2019). Ananda (2016) also suggests that the TOEFL test score is one of the major requirements for admission and graduation in most prestigious universities in Indonesia.

Abboud and Hussein (2011) mentions that the TOEFL test itself has four different formats, which are PaperBased test (PBT), Computer Based Test (CBT), Internet-Based test (IBT), and
Institutional Testing Program (ITP). Especially in Indonesia, most universities apply what is called as TOEFL Prediction test, or so-called TOEFL-Equivalent, whose format is similar to the TOEFL ITP (Mahmud, 2014). Universities provide TOEFL prediction at a more affordable price than TOEFL ITP, and it is used only for internal purposes such as for universities' admission, scholarship, or graduation. Even though the TOEFL prediction is only for local purposes, it is determinative, and its importance is certainly undoubted. Consequently, students must achieve the minimum test score required by the university.

UIN Ar-Raniry Banda Aceh, one of the most leading universities in Aceh Province of Indonesia, was chosen as this research site. This university also regulates their students to prove their English proficiency through the TOEFL prediction score in order for the students to graduate from the university. Especially for English language learners, the minimum score that must be obtained by the students is 500. However, attaining this score still seems problematic for some students. They seem to be struggling to attempt to obtain the required minimum score. Fadhilla (2019), in her study concerning EFL students of UIN Ar-Raniry, claims that it is still hard for the students to acquire the 500 score of the TOEFL test. 
As a result, students have to retake the test several times until they manage to get the needed score.

There are various reasons underlying students' difficulties in succeeding in the TOEFL test. Mahmud (2014) suggests that one factor causing students to struggle to deal with the TOEFL test is the various skills that are evaluated simultaneously at the same test. One solution for this is to have fruitful strategies for each respective skill. Furthermore, in his research, Antoni (2014) found that having a strategy is an essential factor in completing the test. He even proposes that having good strategies is more important than having skills. As the TOEFL prediction test consists of three sections; listening, structure and written expression, and reading comprehension, the test-takers need to have good strategies for each of those sections.

This study is concerned with investigating strategies for the reading comprehension section, especially in reading the text and tackling the questions. This is interesting to be explored since this section is quite challenging. Test takers have to manage answering questions related to long passages in the test in only 55 minutes. Abboud and Hussein (2011) suggest that EFL learners tend to face difficulties in the reading comprehension section of TOEFL due to the test's limited time. Therefore, to answer the section in the allocated time, there should be certain strategies used by test takers. According to Jannah and Fitriani (2018), test-takers' limitation of vocabulary and unfamiliar phrases also hampers them in understanding the meaning of the passages in the reading section, turning them to fail the section. Thus, exploring the strategies effective in reading section is crucial to help future test takers deal with the test.

Studies regarding strategies in preparing for the TOEFL tets, especially in UIN Ar-Raniry, have been done by several researchers (Fadhilla, 2019; Netta, 2019; Hidayat, 2020). However, those studies do not specifically focus on one particular section of the TOEFL test; they are concerned with the TOEFL test in general instead. Meanwhile, as previously mentioned, the reading section of the TOEFL test is quite challenging since the time is very limited, and the passages and the questions that test-takers need to deal with are quite many. Therefore, this study attempts to fill the gap of the condition by investigating the answers to the question 'What are strategies used by UIN Ar-Raniry EFL learners in dealing with the reading section of TOEFL Prediction?' It is expected that this study provides useful strategies 
that future TOEFL test-takers can employ during their preparation for the TOEFL test and the test. In a similar vein, this can also guide TOEFL instructors regarding accommodating their students with appropriate learning strategies in the TOEFL test.

TOEFL, standing for 'Test of English as a Foreign Language', is a standardized test aiming at measuring an individual's proficiency in the English language. It is defined as a test assessing the general knowledge or skills commonly required as an entry prerequisite in an academic institution (Brown, 2005). TOEFL's score can be used as an indicator of someone's English proficiency level to predict their success in other contexts.

According to Abboud and Hussein (2011), officially, the TOEFL test is administered in four formats, which are The Paper-Based TOEFL (PBT), The Computer-Based TOEFL (CBT), The Internet-Based TOEFL (IBT), and Institutional Testing Program (ITP). The first three formats differ only in the different sections the tests have and the equipment used in the test (using paper, computer, or internet). Meanwhile, TOEFL ITP is quite different from the other types of TOEFL tests. TOEFL ITP, which was initiated in 1965, allows a university, institution, or agency to hold their own TOEFL test facilitated by their own staff and used only for their local purposes.

This study uses the term TOEFL Prediction, a TOEFL test provided by the university, UIN Ar-Raniry, with a price much lower than the TOEFL ITP. The test sections in the TOEFL Prediction are similar to those in the TOEFL ITP, encompassing the listening section, structure and written expression section, and reading comprehension section. The test takes place for about two hours and a half, and all of the question items are in the form of multiple choices.

Reading comprehension is the last section of the TOEFL prediction assessing the test-takers' competency in understanding English passages. According to Roger (2005), the reading comprehension section is a part of the test evaluating test-takers' ability to answer the question based on the passages' information. This section consists of four or five passages and fifty questions in which the test takers have fifty minutes to finish.

In this section, the test may ask about the main idea, directly answered details, vocabulary, or overall reviewed ideas (Phillips, 2014). According to Roger (2005), generally, the passages in the reading section are related to a particular realm of knowledge such as science and technology, geology, 
history, geography, culture, art, literature, architecture, anthropology, psychology, sociology, and biography. Even though covering various topics yet, the organization and the texts' style are commonly simple and similar.

The word 'strategy' is defined as subjects that are intentionally and purposively used for particular processes (Cohen, 2006). Reading strategy is intentional acts taken by readers in order to comprehend the text. He (2008) proposes several reading strategies that readers can use to comprehend texts, such as skimming and scanning, analyzing vocabulary, distinguishing between literal and implied meanings, and highlighting discourse markers for process relationships. Furthermore, according to Phillips (2014, cited in Jannah \& Fitriani, 2018), to deal with vocabulary questions, four strategies can be employed: finding out meanings from structural clues, finding word parts, and giving meaning for unfamiliar words by using context. Meanwhile, such strategies as searching for specific information, using background knowledge, and identifying the text's tone or purpose can be used to review questions in the reading section. Having successful reading strategies is essential as Pani (2004) claims that effectively employing strategies is one way to be good readers.
Besides strategies in reading, as mentioned above, Dooden (2015) also proposes another strategy called 'testtaking strategy'. He claims that "testtaking strategies are cognitive abilities to deal with any testing situation in an appropriate manner and to know what to do during tests" (Dooden, 2015 p. 108). Dooden (2015) furthermore mentions examples of test-taking strategies are managing time effectively, surveying all questions before responding, solving easy questions first, eliminating wrong options. Those reading strategies are processes that can be used by testtakers to overcome comprehension failures. Moreover, having test-taking strategies is equally important to have the basic knowledge and information to answer the test questions (Langerquist, 1982).

Reading strategy and test-taking strategy are two different terms, even though they are often confused and may sound overlap. Assiri and Alodhahi (2018) mention that the two are different. The test-taking strategy is not specifically related to any language skills, whereas reading is only about reading skills. Also, reading strategy is about engaging in a reading activity whose purpose is to comprehend texts. In contrast, the test-taking strategy is only used to cope with a test or assignment task. 


\section{METHOD}

This research employed a descriptive qualitative approach. Creswell (2012) defines that a qualitative approach allows the researcher to explore common experiences of an individual to develop a theory. Thus, qualitative study allows researchers to explore phenomena, such as an individual's experience and feelings (Ary, Jacobs, Sorensen, \& Razavieh, 2010). In this study, the qualitative approach was employed to explore students' experience using reading strategies and test-taking strategies in facing the TOEFL Prediction test, especially in the reading comprehension section. Furthermore, a semi-structured interview was utilized in data collection. Thus, it made it possible to ask additional questions about the investigated issue during the interview. The instrument was used to give freedom to the participant and encourage them to speak about their strategy deeply, specifically, in reading the text and answering the questions.

This study took place at UIN ArRaniry Banda Aceh. This study's population was UIN Ar-Raniry students in Tarbiyah Faculty, especially the English Department's 2015 students. The samples, which were six participants, were chosen based on the purposive sampling method. This study purposively selected the students who achieved a score of 500 or more for the TOEFL prediction test and have 35-50 correct answers in the reading section presented by 45-67 scores for their reading comprehension section.

The data analysis was done by following the stages proposed by Ary et al. (2010), which are: (a) organizing and familiarizing, (b) coding and reducing, and (c) interpreting and representing. Therefore, to be familiar with the data, the data from the interview were first organized by listening to the audiotapes and making a transcription. After that, reread the transcription and take notes on what is important. Coding and reducing were done afterward by labelling the data to identify every item or idea derived from the interview. Having been coded, the data which are not related to strategies used by participants in dealing with the TOEFL reading section were then eliminated. The selected data were then interpreted meaningfully and then represented descriptively.

\section{FINDINGS AND DISCUSSION}

\section{Findings}

This study's findings are divided into two parts: strategies used in doing the reading process (reading strategies) and strategies in dealing with the types 
of questions in the reading section (testtaking strategies). The table below summarizes the findings of this study.

Table 1. Reading and Test-Taking Strategies

\begin{tabular}{|c|c|c|}
\hline No & Reading Strategies & $\begin{array}{l}\text { Test-Taking } \\
\text { Strategies }\end{array}$ \\
\hline 1. & $\begin{array}{l}\text { Skimming and } \\
\text { Scanning }\end{array}$ & $\begin{array}{l}\text { Reviewing } \\
\text { questions }\end{array}$ \\
\hline 2. & $\begin{array}{l}\text { Using context to } \\
\text { understand the } \\
\text { meaning } \\
\text { unfamiliar } \\
\text { vocabulary }\end{array}$ & $\begin{array}{l}\text { Prioritizing easier } \\
\text { questions }\end{array}$ \\
\hline 3. & $\begin{array}{l}\text { Utilizing } \\
\text { Background } \\
\text { Knowledge }\end{array}$ & \\
\hline
\end{tabular}

\section{Reading Strategies}

From the interview, it was found that in reading the text, the participants used three strategies: skimming and scanning the passages, using context to understand the meaning of unfamiliar vocabulary, and utilizing background knowledge. All participants are initialed as MS, PK, KM, AK, RZA, and YZ.

Based on the interview, most of the participants mentioned that the strategy they used to answer the reading section was skimming and scanning to search for certain information in the passages.

Question: What are the strategies that you use in answering the reading section of TOEFL?

I skimmed and scanned the passage to get the idea of the text. Because the passages are normally too long, I use the strategy to find the answer fast. [MS]

Furthermore, responses regarding skimming and scanning were also found in the participants' answers when asked whether they applied skimming and scanning strategy in reading the texts.

Question: Do you use skimming and scanning strategy in reading the texts in reading comprehension?

Yes, if I cannot find the answer in the first paragraph, I will skim and scan the passage to look for the text's main idea because it is too boring to read a long passage, so yeah, I'm trying to read it fast. [RZA]

Another reading strategy that the students used was understanding the meaning of the vocabulary by relating them to the context.

Question: What are the strategies that you use in answering the reading section of TOEFL?

So like this, I first checked what the text was talking about. After that, I saw the vocabulary and then tried to relate them to the text's topic. Here, I mean the context of the text. [YZ]

In addition, another participant, RZA, also said:

If I found difficult vocabulary, I would read the sentence that contained the vocabulary. If the sentence talked about 
healthy so the vocabulary should be talking about that too. I just guess it and put the vocabulary into the context of passage. [RZA]

Furthermore, this strategy was not only used to figure out the unfamiliar vocabulary in the passage but also used to answer the closest meaning types of question in the TOEFLs' reading section. As mentioned by PK:

So I looked for the description of the word in the sentence, and then I used the context of the text to understand the certain vocabulary and then answered the question that asked about the closest meaning. [PK]

Finally, the last reading strategy mentioned in the interview was utilizing background knowledge. As most topics discussed in the reading comprehension section are related to general topics such as history, science, or technology, all participants interestingly agreed that their background knowledge helped them comprehend more the topic in the passages and help them answer the questions easily.

So. if I know the topics of the texts, I mean I have the background knowledge about it, I can relate to it even though I just understand the language a little. It eases me to find the answers. [KM]

In line with KM, RZA also asserted the importance of having background knowledge in reading the passages in the reading section:

It is really useful. For example, if I knew about political things, and the passage talked about politics, it is helping me to understand the passage more and ease me to answer the questions. Yes, background knowledge is really important. [RZA]

\section{Test-taking Strategies}

Besides strategies in reading, some strategies may be applied while dealing with questions in the reading section, called test-taking strategies. From the interview, it was found that in coping with the questions in the reading section, the participants employed two strategies, which were reviewing the questions and prioritizing easier questions.

The participants agreed that reviewing the questions before going with the reading process was helpful when doing the reading section.

I usually look for the questions first so that I will only read about what is need to be read to answer the question, not the whole passage. Yeah, like we know that if we read the whole passage first, we will need to read it again after reading the question. [YZ]

$\mathrm{KM}$ also supported the statement:

I just read the question first and look for the keywords of the question, 
and then I read the passage because I can find the answer easily, especially for certain questions. If I read all the passages first, I might forget what I have read, and I need to read it again, and it a waste of time. [KM]

The other strategy to overcome the test found in this study was prioritizing easier questions when answering the test. There were some questions considered easier, and there was a tendency from the participants to prioritize responding to those questions first. As stated by a participant:

\section{I think I would answer easier} questions first, such as vocabulary, because I could find it directly in the text. So, I could move to another question quickly. [MS]

Furthermore, the strategy is considered effective as it can save time during the process of the test:

I think it was very effective, I can save much time, so if I save my time, I can be more focus on the question, and I can finish it well. [PK]

Both of the test-taking strategies found in this study are related to dealing with the section's limited time. As defined by Dooden (2015, test-taking strategies are about what to do during the test. Therefore, in this case, it is about what to do with the limited time of the test; how to contend with the situation.
This study's results indicate that the reading strategy and test-taking strategy are used by the participants to deal with the TOEFL prediction test. This is relevant with Assiri and Alodhahi (2018) claiming that testtaking strategies are essential when dealing with tasks related to reading comprehension.

\section{Discussion}

This study found three strategies that EFL learners used when they read passages in the reading comprehension section. They are skimming and scanning the passages, using context to understand the meaning of unfamiliar vocabulary, and utilizing background knowledge. The idea of using skimming and scanning techniques is not newly introduced in reading comprehension. Jannah and Fitriani (2017) claim that students often skim and scan the passages as one of their strategies in answering the Reading Comprehension section of the TOEFL test. From the participants' responses, it can be deduced that to contend with the long passages, the participants used the strategy not to read the whole texts. As mentioned by Aritonang, Lasmana, and Kurnia (2019), skimming and scanning are applicable strategies that enable test-takers to answer questions related to the main idea or specific information 
without having to read all sentences in the passage.

Furthermore, from the interview, it was also revealed that using the text context enabled the students to understand the unfamiliar vocabulary even though they did not know the exact meaning of the words. It is not easy for EFL learners, who are nonnatives, to know the meaning of all the vocabulary in the test's texts. Therefore, trying to guess unfamiliar vocabulary by relating it to the passage's context can help understand the meaning of the vocabulary. According to Nurhayati (2016), she states that $70 \%$ of her study's participants tried to understand the meaning of certain words by associating the words with the text's context. Having prior knowledge related to the discussed topics in the text, as suggested by some of the participants, is also essential in reading the passages during the test. It can build the reader-text relationship, which leads the readers to get closer to the text. Hasan, Gushendra, and Yonantha (2017) propose that by having relevant background knowledge, ELF learners can better comprehend the text they read since it enables them to correlate their knowledge to the texts' content and context. Jannah and Fitriani (2017) conveyed that $50 \%$ of students tend to use their background knowledge as a good strategy in answering the Reading Comprehension section of TOEFL.

In a similar vein with the reading strategy, the test-taking strategy also plays a pivotal role in facing the reading section. As shown in the findings section, two strategies are found in this study that belong to the test-taking strategy: reviewing the question and prioritizing easier questions.

Dooden (2015) proposes that looking at all the test questions before attempting to answer the questions is one of the successful strategies for testtakers. It sounds logical as Rupp, Ferne, and Choi (2006, cited in Assiri \& Alodhahi, 2018) that multiple-choice questions in the test can guide testtakers in scanning the text. The questions can help locating the certain information needed to answer the questions. As the reading section passages are normally long and the time allocated is limited, surveying all the questions prior to reading the passage helped test-takers read the text with a purpose in mind. They did not have to read for the whole passages, resulting in managing the time more effectively.

Moreover, Dooden (2015) also suggests that one of the good testtaking strategies is the one that can result in managing the time effectively. 
Furthermore, as Abboud and Hussein (2011) argue, one of the difficulties students face when taking a test is that the time available is not sufficient; therefore, it is believed that students who have more time in the test will have better performance for the test. Not only can the test-taking strategy help students manage the time, but it also helps test-takers reduce test anxiety that they may experience. One of the participants claimed that having strategies could get rid of their nervousness when working on questions on TOEFL and increase their confidence, which in their opinion, can help them perform well in the TOEFL test. This is in line with Dooden (2015) arguing that test-taking strategies indirectly minimize test anxiety felt by test-takers.

\section{CONCLUSION AND SUGGESTION}

As the reading section of the TOEFL test consists of several long passages with 50 questions in total; therefore, it is unquestionable that fruitful strategies are crucial to succeed in the section. From the interview result, it was found that three reading strategies can be applied during the TOEFL reading section, which are skimming and scanning the passages, using context to understand the meaning of unfamiliar vocabulary, and utilizing background knowledge.
Furthermore, two strategies can be used in dealing with the questions provided in the reading section, so-called testtaking strategies; they are reviewing the questions and prioritizing more straightforward questions. Hopefully, knowing these five strategies can help EFL learners and other test-takers deal with the reading comprehension section of the TOEFL test. It is hoped that EFL learners can apply these strategies and succeed in achieving the targeted TOEFL score. Besides, the findings are also expected to be guides for TOEFL instructors in preparing their students to be successful in the TOEFL test. To conclude, this study has explored the strategies that may be used in facing TOEFL reading section; however, further study exploring the effectiveness of particular strategies in improving students' performance in facing the section is suggested in order to strengthen the existing findings in this area of interest.

\section{REFERENCES}

Abboud, Z. A. R., \& Hussein, N. J. (2011). The difficulties faced by advanced Iraqi foreign learners in passing ITP TOEFL test. Journal of Basrah Researches (Humanities Series), 36(4), 110-138.

Antoni, R. (2014). An analysis on 6th semester students' TOEFL experience at English Department of Teachers Training and Education Faculty of 
Pasir Pengaraian University. Journal Ilmiah Edu Research, 3(1), 9-16.

Ananda, R. (2016). Problems with Section Two ITP TOEFL test. Studies in English Language and Education, 3(1), 35-49.

Ary, D., Jacobs, L. C., Sorensen, C., \& Razavieh, A. (2010). Introduction to research in education. (8 $8^{\text {th }}$ ed.). Cengage Learning.

Aritonang, I. R., Lasmana, S., \& Kurnia, D. (2019). The analysis of skimming and scanning technique to improve students in teaching reading comprehension. PROJECT (Professional Journal of English Education), 1(2), 101-106.

Assiri, M. S., \& Alodhahi, E. A. (2018). Testtaking strategies on reading comprehension tests: A review of major research themes. Studies in English Language Teaching, 6(3), 207227.

Brown, D. H. (2005). Language assessment: Principle and classroom practices. Pearson Education.

Creswell, J. W. (2012). Qualitative research design: An interactive approach (4th $\mathrm{ed}$.). Sage.

Cohen, A. D., \& Upton. (2006). Strategies in responding to the new TOEFL reading task. Retrieved from https://www.ets.org/media/research/pdf/ RR-06-06.PDF.

Dooden, H. (2015). Teaching test-taking strategies: Importance and techniques. Psychology Research, 5(2), 108-113.

Fadhilla, F. (2019). Exploring EFL students' preparation in taking TOEFL Test. UIN Ar-Raniry Banda Aceh
Halim, N., \& Ardiningtyas, S. Y. (2018). Difficulties faced by the students in answering TOEFL test questions. English, Teaching, Learning, and Research Journal, 4(2), 219-231.

Hasan, A., Gushendra, R., \& Yonantha, F. (2017). The influence of prior knowledge on students' listening and reading comprehension. IJEE (Indonesian Journal of English Education), 4(1), 1-15.

He, T. (2008). Reading for different goals: The interplay of EFL college students' multiple goals, reading strategy use and reading comprehension. Journal of Research in Reading, 31(2), 224-242.

Hidayat, T. M. (2020). An analysis of learning strategies among students with 500 TOEFL score or above. UIN Ar-Raniry Banda Aceh.

Langerquist, S. L. (1982). Addison-Wesley's Nursing Examination Review. Addison-Wesley.

Jannah, M., \& Fitriani, S. S. (2018). EFL students' strategies dealing with common difficulties in TOEFL Reading Comprehension Section. International Journal of Language Education, 1(1), 29-36.

Mahmud, M. (2014). The EFL students' problems in answering the test of English as a foreign language (TOEFL): A study in Indonesian context. Theory and Practice in Language Studies, 4(12), 2581-2587.

Netta, A., \& Trisnawati, I. K. (2019). Acehnese undergraduate students' strategies in preparing for TOEFL Prediction: A Preliminary Study. Englisia Journal, 7(1), 41-52. 
Nurhayati, N. (2016). An analysis of students' strategies in answering TOEFL. The Journal of English Language Studies, 1(1), 10-18.
Pani, S. (2004). Reading strategy instruction through mental modelling. ELT Journal, 58(4), 355-362.

Phillips, D. (2014). Longman Preparation Course for the TOEFL Test. Longman. 